Seattle Pacific University

From the SelectedWorks of Heather Ingersoll

Fall November, 2014

\title{
Making Room: A Place for Children's Spirituality in the Christian Church
}

Heather Ingersoll, Seattle Pacific University 


\section{Making room: A place for children's spirituality in the Christian church}

Heather Ingersoll

School of Education, Seattle Pacific University, Seattle, USA

This is an Accepted Manuscript of an article published by Taylor \& Francis in International Journal of Children's Spirituality on November 19'2014, available online:

http://www.tandfonline.com/doi/abs/10.1080/1364436X.2014.979774. 


\section{Making room: A place for children's spirituality in the Christian church}

A relatively uncharted territory until recently, the concept of children as innate spiritual beings has garnered significant attention among scholars over the past two decades. The more that is learned about children's spirituality the more apparent it becomes that the Christian church in the United States generally fails to provide sufficient space for children to explore, develop, and share their spirituality. This potentially leads children to suppress or disconnect from their spirituality in later years and also deprives a Christian community of the ability to learn and grow from children's unique experiences of God and spirituality. This paper examines the underlying theories that foster environments among Christian churches where the ennoblement of a "grown-up faith" and the resulting power adults hold because of that, inhibit the ability for children to be regarded and approached as capable of spiritual and faithful beliefs and understanding apart from adult intervention.

Keywords: Christian church, Sunday school, Adultism 
I was feeling real scared, real upset... and I got so scared I started crying, and then all of a sudden, I saw the door open, and there was a flash of light outside; it was like lightening, and I think it was Jesus. He'd come to help me. - 9 year old girl describing a dream from (Coles, 1990, 131)

At night, a lot, I'll be looking out the window, and it's real quiet, and you can sit and wonder if there are people like you up on other planets or stars; and you can wonder whether there is a God watching you - or maybe there are several gods, or lots of them, or angels, I don't know, but I think about it, and how it's not fair...that you and I are healthy, and others, your brother aren't.- 12 year old boy, Norman (Coles, 1990, 298).

These excerpts from Robert Coles' (1990) book, The Spiritual Life of Children provide

the reader with a glimpse into the intricate inner lives of these children. Coles' research (1990), well regarded as seminal work in the field of children's spirituality, offers important insight into the spiritual capacities of children. An overlooked treasure of the book is Cole's personal commentary in which he intertwines the children's words with his own struggles of when and how to respond and the childhood memories and questions that are elicited from the children's words. Coles models a way for adults to listen to children and allow them the space to express their inner spiritual lives and wrestle with deep existential questions. Many other adults have a voice in this book; the parents, Sunday school teachers, nuns, priests, and others, who are referred to by the children as having influenced their spiritual lives, some in positive ways and some in more negative ways.

The Spiritual Life of Children is one resource in a growing body of literature in which the concept of children as innate spiritual beings is garnering significant attention among scholars. Researchers such as Robert Coles (1990), David Hay and Rebecca Nye (2006), Tobin Hart (2006), and Brendan Hyde (2008) provide practitioners with the opportunity to gain a deeper appreciation of the spirituality of children and their ability to seek and contemplate spiritual concepts (Ratcliff, 2007). This represents research from various contexts, Coles' research comes from children around the world, Hay and Nye's research focused on children in the United 
Kingdom, Hyde investigated children in Australia, and Hart's research is from the United States. This empirical research, from various international perspectives, serves as a foundation for theorists to develop guides for practitioners to understand how to better nurture the spiritual lives of children (Allen \& Ross, 2012; Beckwith, 2004; Csinos, Jennings, McClaren, \& Yust, 2002; Nye, 2011).

This article is written from my perspective after serving on staff in children's ministry in primarily white middle-class mainline denominational churches in the northwest and mid-west parts of the United States. The impetus for this paper comes from the disconnect I experience between evidence from scholarly research and current practices to support children's spirituality within churches I am connected to from personal experience or through colleagues. This is a unique perspective from a practitioner working to make sense of experiences within the church in light of academic literature. Literature detailing children's ministry in different contexts particularly African-American, Latino, and Korean churches in the United States, (Baker, 2010; Crozier \& Conde-Frazier, 2004; Haight, 2002; Tolbert \& Brownlee, 2009) indicates that the challenges to supporting children's spirituality in those contexts may differ from the barriers espoused in this article. My experience from a predominately white mainline church context reflects what prominent scholars in the field in the United States seem to identify, that the church generally fails to embrace new understandings of children as spiritual beings. Current approaches with children in many mainline denominational churches often manifest in environments governed by adults that stifle the opportunity for children to explore their own spirituality and relationships to God. This paper will highlight four barriers that hinder the church from transitioning to a more holistic approach to ministry with children in light of emerging understandings of the complexity of children's spiritual lives. 


\section{Definitions}

An overview of the literature reveals the complex and intricate spiritual lives of children, which indicates that a simple definition does not adequately encapsulate the multifaceted nature of children's spirituality. A holistic understanding of children's spirituality will honor the varied voices that provide insight into this delicate dimension of human life (Ratcliff \& May, 2004). Roehlkepartain (2004) states '[I]t seems premature — and potentially counterproductive - to propose that a particular definition could adequately capture the richness, complexity, and multidimensional nature of this domain of human life' (121).

Empirical research designed to investigate children's spirituality primarily focuses on children's ability for 'spiritual processing' (Nye, 2004, 90).

It turns out that children, partly by virtue of their distinctive psychological characteristics, have an intriguing rich capacity for spirituality, for a kind of religious knowing and being which is neither contingent on their religious knowledge nor moral accountability (93).

Hyde (2005) describes children spirituality in four specific characteristics; felt sense, integrating awareness, weaving threads of meaning, and spiritual questing. Hay and Nye (2006) developed the term "relational consciousness" to describe the spirituality of children they found to be innate and integral to every child's being. Coles' (1990) writes that children are 'young pilgrims, well aware that life is a finite journey' (p. xvi). Descriptions of children's spirituality based on the research by Coles (1990), Hay and Nye (2006), and Hyde (2005) provide a framework for exploring how children are agents and participants in their spiritual lives, while acknowledging the adult's role in providing wisdom and guidance to the child's experience.

\section{Children as spiritual agents}


In November 1989 the United Nations General Assembly adopted the Convention on the Rights of the Child (CRC) (Office of the High Commissioner for Human Rights, 1990). The CRC, made up of 54 articles, is a legally binding document with guiding principles to allow children the rights afforded to them (Office of the High Commissioner for Human Rights, 1990). The development of the CRC supports the emerging understanding of children as valued participants in their families and communities (Hart, 1992). The view of children as active agents in shaping their own development is garnering attention in the literature from various fields including sociology, psychology, education, and theology (James \& James, 2001). This literature includes an exploration of how the perception of children as active agents will shape and change future approaches to the treatment of children (James \& James, 2001).

The understanding of children as innate spiritual beings is further solidified when children are thought of as active participants in their own spirituality, instead of passive recipients of knowledge about God (Hyde, Yust, \& Ota, 2010). As seen in conversations children had with Coles (1990), adults have a significant influence on children's religious understanding. The power dynamics between adults and children in the Christian church in the United States should be explored and addressed to provide children with more active participation in their experience in the church and programs designed to nurture their spirituality.

\section{Barriers}

In order to provide a beginning point for moving forward, it is proposed that the following four aspects of the Christian church in the United States are barriers to creating a holistic environment for the nurture of children's spirituality: ennoblement of adult faith, reliance on content acquisition, token opportunities for children's participation, and adultism.

\section{Ennoblement of adult faith}


Developmental stage theories, formulated by Piaget, Kohlberg, Fowler and others, dominated literature on children's faith formation in the twentieth century and provide the central framework for many Sunday school curricula and models of children's Christian education today (Estep \& Beckenridge, 2004; Hay, Nye, \& Murphy, 1996; Miller-McLemore, 2010; Ward, 1995). A child's ability to grasp faith is often seen through a developmental stage theory lens, leading to the inference that children are incapable of 'genuine spirituality' until adolescence or adulthood when they are understood to have the capacity for meaningful reflection and abstract thinking (Hart, 2006, 163). Hay, Nye \& Murphy (1996) suggest:

Over the past thirty years the dominance of cognitive development theory in the field of religious education has led to a severe neglect of the study of spirituality of the child and to a distortion of what goes on in the religious education classroom (47).

Developmental stage theories, particularly James Fowler's (1981) faith stages theory, provide positive guidance for leaders in children's Christian formation particularly for the development of age appropriate opportunities for children in the church (Dettoni \& Wilhoit, 2002). Fowler is clear that the faith stage theory is not designed as an 'achievement scale' or a representation of 'educational or therapeutic goals' (114). He invites his readers to 'playful seriousness and serious playfulness' (xiv) noting that his theory only provides one piece of the larger story of human faith. However, an in-depth look at practices developed in the church based on Fowler's stages of faith, indicates an over reliance on this one theory. This limits the perception of children as spiritual beings by elevating the 'final frame' of adult faith (MillerMcLemore, 2010).

The adoption of developmental stage theories as the primary framework for guiding practice with children in the Christian church often leads to the ennoblement of the faith of adults 
over the faith of children. From this perspective adults have an element of 'expert power' (French \& Raven, 1959) seen as possessing 'special knowledge or expertness' (263). This power is evident in adult-children relationships where the interactions are adult-centered, forming a 'one-way flow of communication' (Haight, 2004, 109). In settings where grown-up faith is valued as the arbitrary ultimate goal, children's questions, speculations, and thoughts are often discouraged or ignored (Haight, 2004; Yust, 2002). The limited view of children's capacity to think spirituality, derived from developmental stage theories, can lead to the elevating of adult faith as the ultimate goal, leaving little room to embrace children as valuable participants in their own spirituality and in the spirituality of the community.

\section{Reliance on content acquisition}

According to Haight (2004), the majority of research on children's religiosity and spirituality, from a Christian perspective, has focused on cognition and capacity for religious and Biblical knowledge. The emphasis on cognitive understanding is also seen in Sunday school curricula developed by major publishers in the United States. In the Faith Formation in Children's Ministries project, Karen-Marie Yust (2002) discovered a strong push for children to acquire Biblical knowledge in the churches she observed. She writes that children are typically seen as 'vessels' needed to be filled with information in order to gain faith rather than understood as capable of their own faith (Yust, 2002,4). Children don't truly belong to the church as active participants but rather as passive recipients of educational programs (Yust, 2002, 4). Yust (2002) describes several situations where she observed teachers as 'uncomfortable' when children began talking about their experiences because it distracted from the lesson for the day (8). She also observed several incidents where students opened the door for meaningful conversations around significant topics where the teachers ignored the student's inquiries or changed the topic to 
seemingly get the class back to the important points of the lesson. It appeared as though the teachers had an agenda with little room for straying from that agenda to focus on the children's wonderings, questions, or thoughts (Yust, 2002, 8-9).

Nye (2004) asserts that children's natural ability to process their spirituality is neglected in the church 'whose concern has been installing spiritual comprehension software to the awkward hardware with which children are equipped' (90). She suggests the focus on growing religious knowledge may stifle children's innate ability for spiritual knowing and being. This focus on acquisition of Biblical knowledge impacts the way adults respond to children's natural wonderings. When children inevitably ask questions or point out contradictions in the text or the lesson, adults are often quick to offer counter-arguments to explain in rational terms what they want the children to believe (Nye, 2004, 99).

The emphasis on knowledge acquisition presents several problems when it comes to creating space for the nurture of children's spirituality in the church. Most programs for children in the church are centered on a once a week educational opportunity that lasts around an hour and is often led by volunteer teachers who are there two or three times a month. When the primary goal for a program is content acquisition, and the program is limited in time and resources, there is little room for children to engage in opportunities for wonder and reflection on the material.

When we tightly script teacher's roles and insist on children's busyness and productivity through numerous activities and rewards for quickness, we fail to communicate the value of silently experiencing or pondering the amazing love of the God upon whom we depend for our creation, redemption, and sustenance (Yust, 2002, 4).

The reliance in the Christian church on words to help children understand the Christian faith can 
potentially 'diminish a child's wonder' (May \& Ratcliff, 2004, 161).

Ruppell (2004) argues that children's Sunday school classes are often based on adult's views about what children should know or learn instead of the real needs of the children. The focus on knowledge acquisition and adult desires to get their lessons across or have children adopt a certain set of beliefs, limits the opportunity to nurture the important aspects of children's spirituality including wondering, awe-sensing, questioning, and creativity. Focus on knowledge acquisition also limits the potential of adults to experience and learn from children's beliefs and experiences.

\section{Token opportunities for participation}

Hart (1992) describes tokenism as 'those instances in which children are apparently given a voice, but in fact have little or no choice about the subject... and little or no opportunity to formulate their own opinions' (9). Recently developed practices in children's programming in the Christian church adopted as an attempt to develop a more child-centered approach, offer little more than a token approach to children's participation in their own spiritual growth. Those trends include entertainment-based programs and the separation of children from adult worship.

\section{Entertainment based programs}

In the 1990's many church leaders adopted the notion that church should be the most fun experience in a child's week (May, Posterski, Stonehouse \& Cannell, 2005). May et al. call this approach to ministry the 'carnival model' where children experience an atmosphere similar to Chuck E. Cheese or a McDonalds playhouse. In this entertainment based space children are encapsulated with bright colors, elaborate sets, funny skits, flashy media, loud music, and energetic games. While this approach is not inherently bad, it does not provide the necessary space to nurture the spirituality of many children. As May et al. assert some children 'may feel 
overwhelmed or lost in such a setting' limiting the potential for children to experience moments of wonder and awe (16).

In their qualitative research with 13 children from Christian churches in the United States, Bellous and Csinos (2009) describe one boy Caleb, who attended a church with an 'upbeat' Sunday program for children (222). Caleb describes his intimate connection with God, a connection he is acutely aware of when outside and during his regular practice of reading scripture. Bellous and Csinos describe Caleb as feeling annoyed, frustrated, and disconnected from the children's programming at his church as exemplified in his statement 'I feel like they're saying that there are not mysteries of [God]...when I know there are' (Bellous \& Csinos, 2009, 222). Caleb represents the stories of children who long for quiet, reflective opportunities to experience God, stories that get drowned out by the many voices that advocate for children to be entertained, busy, and have fun.

Thomas (2009) found that children's pastors she interviewed in her research in Christian churches in the Houston area had 'mixed-feelings' about entertainment-based programs, noting the lack of silence and 'documented spiritual benefits' as concerns (68). This type of programming is based on a limited assumption of children and their spiritual needs. Illusive anecdotal measurements of success such as, the number of participants or the energy level of the children, make this approach deceitfully appealing and difficult to overcome in the light of new research on children's spirituality.

\section{Children's worship}

Children's church is a popular method for engaging children in worship opportunities apart from the regular adult worship service. In this model two age segregated worship services happen at one time, with adults and children separated for their own experiences. This model is 
built on the assumption that children must practice worship in an age appropriate way to prepare them for adult worship later on in life. Yust (2002) quotes a colleague of hers saying 'most children's church programs are more likely to be experiences of "worship impoverishment" than the "worship enrichment" experiences church leaders claim them to be' (12). In this approach childhood is viewed primarily as a time of preparation for adult worship, which is attained at some age specified time in one's life ignoring the reminder from Rahner (1971) that 'Childhood itself has a direct relationship with God' (37). Mercer (2005) asserts that the practice of separating children from adult worship takes away from the opportunity for children to be formed in the practice of the community, so they are confined to formation in the Sunday school or children's worship practices.

While there may be noble intentions behind entertainment-based programs and children's worship and they may appear to be ideal models for integrating children into the Christian church, they fall short. Evaluation of these models in light of empirically based descriptions of children's spirituality highlight the deficiencies in these approaches where children are provided token and limited opportunities for participation stifling opportunities for their spirituality to flourish.

\section{Adultism}

A final barrier to developing better practices for nurturing children's spirituality is seen in the priority of adult needs. This is perhaps the most limiting of all the barriers. The priority placed on the needs of adults can be seen in various practices in the Christian community primarily in worship. Dillen (2007) asserts there is a 'lack of sensitivity to the participation of children in our society' (43) using the term adultism to describe situations when 'the work of adults is generally seen as more important than the play of children' (42). Miller-McLemore 
(2003) uses the term adultism to describe anything that diminishes the rights of children. There are aspects of adultism in the Christian church that limit the experiences afforded to children in the church.

\section{Children in worship}

Participation in the worship life of the congregation is found to have a positive influence on children's spiritual development and is considered by many scholars to be a best practice in the nurture of children's spirituality (Roeklkepartain \& Patel, 2006; Beckwith, 2004; Thompson, 2009; Allen \& Ross, 2012; Miller-McLemore, 2006; Bunge, 2009). Despite a significant amount of literature focused on the importance of children's participation in the corporate worship of the entire church, the trend to pull children out of worship continues (Campagnola, 2004).

Campagnola asserts that children are perceived as distractions to the worship of the congregation, seen in the "[i]ncreasing movement in our churches to separate the children from the adults for their own worship and teaching, and to protect the so-called "intimacy" of the worship and teaching of adults' (Campagnola, 2004, 73). Mercer (2005) notes other typical reasons for removing children from the regular worship life of the community including the complaint that the presence of children requires alteration of the liturgy or the sermon to be more accessible for children for fear they will be bored or restless. Adults 'mask' their desire to remove children from the community because it is too 'messy' and 'complicated' by the rhetoric that their true concern is the developmental needs of the children (Mercer, 2005, 189).

When children do sit in the adult worship service, there is often a narrow adult biased approach to the children's participation. In some cases congregational members want to see the children in worship because they are valued more as a 'symbol of vitality' for the congregation, rather than seen as valuable participants in the faith community, demonstrated in the 'uncritical 
and casual' way children are invited to actively engage (Mercer, 2005, 214) Their active engagement is typically limited to opportunities to sing in a children's choir or to go to the front of the church for a children's sermon. Ng and Thomas (1985) wrote about practices such as children's sermons and children's choirs as 'discriminatory' practices that further compartmentalize children's experiences in the churches, relegating their participation to special age-segregated practices. The elevation of adult's needs over children's needs is seen in areas beyond worship, even those areas designed specifically for children, such as Sunday school. Sunday school volunteers

In her dissertation, Thomson (2009) interviewed children's pastors from a diverse group of churches in the Houston area, to explore what criterion was used to choose Sunday school curriculum. Thomson discovered that the primary criterion for choosing Sunday morning curriculum was ease of use for the teacher (66). In her conversation with a pastor in one of the congregations, Thomas (2009) was told that it is difficult to get volunteers to work with the youngest children because of the amount of energy it took to care for the children. While this was a small study in a specific area of the country, it raises questions about motivations behind curriculum decisions. As Thomson suggests, this study provides a framework for further research that investigates motivations behind materials used in Christian education with children and further investigates how those materials and programs nurture children's spirituality. Furthermore, the difficultly in finding volunteers to commit to leading children's programs raises questions about the lack of concern for the needs of the children over individual adult needs.

When the spiritual nurture and faith of adults are viewed as more important that those of children adultism pervades the church. Many of the practices involving children in the Christian church are adopted with heavier value placed on adult preferences. Motives for decisions that 
favor the adults may include the desire for quiet, distraction free worship, the comfort that comes from signs of vitality and future sustainability of the institution, or the joy that comes from children's performances. While adult's desires are important, the church will never reach a more balanced approach to nurturing children's spirituality without placing a greater emphasis on the perspective of the needs of children.

\section{Future directions}

While the term barrier denotes something that halts progress, it may be more productive in this case to view each barrier as an inception from which something more holistic can develop. The barriers have the potential to become a foundation for the movement from one limited approach to ministry to broader ministry practice. The possibilities for transformation within these barriers is described as moving from (a) ennoblement of adult faith to the centralization of child faith, (b) the reliance on content acquisition to dependence on individual and communal sacred experiences, (c) tokenism to shared participation and (d) adultism to intergenerational ministry. The following theoretical and practical examples are suggested as possible resources for making these transitions.

Ennoblement of adult faith to the centralization of child faith

One of the most profound passages of scripture relating to children is found in Matthew 18. In this passage, the disciples ask Jesus who will be the greatest in the kingdom of heaven. Their question implies a linear, hierarchical view of God's kingdom, where the faith of some is elevated above others. As Jesus does so often throughout scripture, he invites the disciples to think from a new paradigm by saying 'Truly I tell you, unless you change and become like little children, you will never enter the kingdom of heaven' (Matthew 18:3 New International Version). Jesus' words to the disciples provide a stark contrast to a stage theory of faith 
development that implies the need for linear movement to a more perfected faith that is only capable in adulthood. Rather, his words challenge Christians to explore the faith of the child as a centralizing perspective.

Leaders in the Child Theology Movement, an emerging theological framework, are committed to exploring the practical implications of Jesus' words in Matthew (White \& Willmer, 2006). They seek to frame theological inquiry and dialogue through the lens of the "child in the midst' (White \& Willmer, 2006). Resources from this movement provide insight into varied perspectives on how this theological lens may influence and change practice for children and adults in the church. While there are varied approaches to interpreting childhood within the Child Theology Movement, there remains a commitment to a balanced perspective that considers the rights of the child without idealizing childhood, and is faithful to God's leading. This growing body of theological work may provide helpful guidance for the movement to centralizing child faith.

From reliance on content acquisition to dependence on sacred experiences

The second movement requires a broadened perspective of educational theory and of faith development. John Westerhoff, III is well known for his critique of the schooling model of Christian education. In his book (1976) Will our Children Have Faith? he argues for a model of Christian education that relies less on a schooling method and more on socialization or enculturation of children into the faith through participation in the church community. Social theories of learning can provide alternative frameworks, to help guide the movement beyond focus on content driven approaches to children's faith formation.

Estep and Breckenridge (2004) propose the use of the ecological model developed by Bronfenbrenner (1979) as a framework for the formation of children's spirituality. 'The 
awareness of the ecological interconnectedness of human systems with one another can constitute a fundamental shift that views spiritual formation as embracing the totality of human existence' (Estep \& Breckenridge, 2004, 333). Hood (2004) investigated the formation of children in Christian churches using Bronfenbrenner's ecological theory of development as a guide. She describes children as being shaped in the congregation not only by experiences in programs they attend, but also by their comprehensive experience in the congregation. This theory broadens the view that children are only shaped by programs designed for them, to encompass the reality that the larger social settings in which children are situated, including the church community, influence them as well.

Jerome Berryman is also well known for his critique of a schooling method, or cognitive focused curriculum for faith development. In a response to his search for a more appropriate curriculum, he developed Godly Play (2006), a Montessori based approach to Christian education that allows children time to wonder and experience God. Godly play is used as a Sunday school curriculum in many churches in the United States, especially Episcopal churches (Hadaway, 2005), but is also increasingly used in various Christian denominations all over the world. The guiding assumption for the curriculum is that children experience God, and the role of Christian formation is to help them develop a Christian language in order to make meaning of those experiences. Berryman argues that Godly Play is just as valuable for adults. He writes 'The goal of Godly Play is to nourish the spiritual practice of children and adults for the spiritual maturity of both' (2009, p. 198).

Children in a Godly Play classroom begin by listening and entering into a carefully crafted Bible story presented by a trained storyteller using physical materials. The children are then asked wondering questions in a safe space where each expression is responded to with grace and 
acceptance. The children are then given space and time to reflect on the story using a variety of possible mediums. The Sunday school room is transformed from a classroom for learning to a sacred space for experiencing God. It becomes a space where children can express their questions, their doubts, and their grand imaginations without being corrected or redirected to a more conventional way of thinking.

In Godly Play, there is also a transformation of the power differentiation between adult and child. The adult storyteller sits in a circle with the children. This 'reduces the adult's dominance' by creating an environment where they are a 'minority partner' (Berryman, 2009, 199). The use of physical materials to tell the stories allows people with various cognitive abilities to grasp and reflect on the story together. Both adults and children are impacted when children are invited to be a part of theological reflections. Most notable is the use of wondering questions as a way to honor the voices of children. They 'help free children's theologizing from adult control and the tendency of adults to tell them how to think and feel' (199). Whether adopted as a Sunday school curriculum, used for intergenerational classes, or used as a guide for other ministry practices, Godly Play is a model of how adults and children can be involved in the same activity and both make meaning from their sacred experiences of God.

From tokenism to shared participation

Situated learning theory, a theory based on an apprenticeship approach to learning, developed by Lave and Wenger (1991) provides a framework for allowing children to be formed by their experiences as full participants in the church community. This theory is based on an apprenticeship approach to education and is recognized as a valuable guide for viewing the nature of children as learners in the church (Allen, 2009; Mercer, 2005). It is grounded in the notion that 'learning is an integral and inseparable aspect of social practice' (Lave \& Wenger, 
1991, 31). Learners are considered 'newcomers' who develop and learn through full participation in the practices and values that shape their community (Lave \& Wenger, 1991). Mercer (2005) asserts that children can be approached as 'genuine apprentices of Christian faith and life' by being given full access to participation in the community and both learning from and shaping the core practices of that community (201).

Hart (1992) developed the Ladder of Participation, a visual guide to inspire organizations to reimagine how children are valued as participants. The three lowest levels on the ladder are 'manipulation', 'decoration', and 'tokenism', all examples of situations where children do not have rights to participation. The ladder ascends into increasing levels of participation to the final seventh and eighth levels that are 'child-initiated and directed' and 'child-initiated shared decisions with adults' (Hart, 2008, 22). Church leaders can use this valuable and simple tool to evaluate and explore ways to increase opportunities for children to participate in the church community. This participation may involve allowing them space for their voice to be heard in church committees or meetings, inviting them to express their faith and share their stories in congregational events, and empowering them to be integrally involved in the life of the congregation through opportunities for leading worship, teaching classes, creating art for the building, and serving.

From adultism to intergenerational ministry

Allen and Ross (2012) define intergenerational ministry as a community that 'intentionally brings the generations together in mutual serving, sharing, or learning within the core activities of the church in order to live out being the body of Christ to each other and the greater community' (loc. 160). They argue that intergenerationality is not a program or model but a new mindset that requires a reorientation of 'mind, spirit, and body' within the leadership 
and organization (loc. 1628). There is no one model or guide for how to reorient a congregation to be more intergenerationally sensitive. It may happen in gradual ways or specific ways through opportunities for people from various generations to participate together in social events, storytelling, service, and classes (Roberto, 2009). A truly intergenerational ministry requires a way of being in community in which the needs and influences from each generation are viewed as important. It often begins by providing space for people of various ages to be together and build relationships with one another.

Messy Church is a model of intergenerational ministry (Messy Church, 2014). In Messy Church the focus is on developing practices that embrace the spiritual diversity of all ages (Lings, 2013). The Messy Church movement started in Europe and is now used around the world. It is a fresh expression of church that utilizes hands-on expressions, food, and fellowship to engage people of all ages in an experience of worship. As stated earlier, there is a tendency to marginalize children within the church community by making decisions based on the needs and desires of the adults. In Messy church this tendency is counteracted because the play of children is emphasized with a conviction that the faith of adults will be encouraged and deepened through those play experiences as well. The model combines relationship-building, outreach, and all-ages experiential worship to invite non-believers and believers of all ages to experience and connect with God and one another in new ways (Messy Church, 2014). The ability of this model to connect with so many people around the world provides insight into the value of a space and experience that speaks to all ages, and practical ideas of how it can work.

The movement away from adultism to intergenerational ministry does not require pure abandonment of age-segregated ministry. According to Allen and Ross (2010) 'Churches that embrace an intergenerational culture also deeply value the unique and important place of age- 
graded learning settings' (Loc. 1296). There may still be an age-specific Sunday school class, mid-week program, or summer camp. The movement from adultism to more intergenerational ministry should not only be a movement to gather generations together, but it should include a commitment to care for and protect the needs of all the generations. When decisions are made about programs specifically designed for children, the play of the child should be valued above the work of the adult. Curriculum choices should be made based on the needs of the children and the nurturing of their spirituality. Those leading ministries with children should have a high level training on educational theory and spiritual development and the skills to create environments that support children's spirituality. Adequate financial resources should be allocated to ensure leaders have the resources to provide strong programs. Placing high priority on the spiritual nourishment of the children in the church will not only benefit the children and their families, but will also provide surprising and lasting benefits for members of all ages.

\section{Conclusion}

The hope is that these examples can be used as resources or models for ways in which the church can better support the spirituality of children. The growing body of literature around children's spirituality and the rights of children as agents and participants in their own social contexts should continue to provide a framework to better understand children as spiritual agents. Attention must be paid to identify the fundamental barriers that halt changes toward providing the spiritual opportunities children thrive under in the church and investigating how to use those barriers as a foundation for change.

While at times it seems like a daunting task to move beyond institutional barriers that relegate the roll of children to passive recipients versus active participants in their spirituality, it is an important one. The work of Robert Coles (1990) in The Spiritual Life of Children is a 
reminder of the value in taking on that task. Coles provides an entire book of examples that show the potential children have for an inspiring level of depth in their ability to grasp and wrestle with spiritual issues. As Robert Coles so aptly models for adults, not only do children need opportunities to work out their spiritual wonderings, but adults can benefit greatly by listening and learning from the unique insights children have as fellow pilgrims on the spiritual journey. 


\section{References}

Allen, H. C. (2009). Building the generations together: Support from learning theory. Lifelong Faith, 3(1), 3-11. http://www.lifelongfaith.com/uploads/5/1/6/4/5164069/lifelong_faith_journal_3.1.pdf

Allen, H. C. \& Ross, C. L. (2012). Intergenerational Christian formation: Bringing the whole church together in ministry, community and worship. Downers Grove, IL: InterVaristy Press. [Kindle DX version]. Retrieved from Amazon.com

Baker, D. G. (Ed.). (2010). Greenhouses of Hope: Congregations Growing Young Leaders Who Will Change the World. Herndo, VA: Rowman \& Littlefield.

Beckwith, I. (2004). Postmodern children's ministry. Grand Rapids, MI: Zondervan.

Bellous, J. E., \& Csinos, D. M. (2009). Spiritual styles: creating an environment to nurture spiritual wholeness. International Journal of Children's Spirituality, 14, 213-224. http://dx.doi.org/10.1080/13644360903086471

Berryman, J. W. (2009). Theologizing with children: A parable approach. In G. Y. Iversen, G. Mitchell \& G. Pollard, (Eds.), Hovering over the face of the deep: Philosophy, theology and children (pp. 197-214). Münster, Germany: Waxmann Verlag.

Bunge, B. M. J. (2009). Biblical and theological perspectives on children, parents and 'best practices' for faith formation: Resources for child, youth, and family ministry today. Dialog: A Journal of Theology, 47(4), 348-361.

Campagnola, S. (2004). Unless you become as one of these: Biblical perspectives on children's spirituality. In D. Ratcliff (Ed.), Children's spirituality: Christian perspectives, research, and applications (pp. 72-89). Eugene, OR: Cascade Books.

Coles, R. (1990). The spiritual life of children. Boston, MA: Houghton Mifflin. http://www.baylor.edu/content/services/document.php/117022.pdf 
Crozier, K. \& Conde-Frazier, E. (2004). A narrative of children's spirituality: African American and Latino theological perspectives. In D. Ratcliff (Ed.), Children's spirituality: Christian perspectives, research, and applications (pp. 284-308). Eugene, OR: Cascade Books.

Csinos, D. M., Jennings, D. L., McLaren, B. D., \& Yust, K. M. (2002). Where are the children?: Keeping sight of young disciples in the emerging church movement. Family and Community Ministries. Baylor University School of Social Work. Retrieved from http://www.baylor.edu/content/services/document.php/117022.pdf

Dettoni, J. M., and J. C. Wilhoir. 1995. “Introduction.” In Nurture That is Christian: Developmental Perspectives on Christian Education, edited by J. C. Wilhoit and J. M. Dettoni, 7-17. Grand Rapids, MI: Baker Books.

Dillen, A. 2007. "Religious Participation of Children as Active Subjects: Toward a Hermeneutical-Communicative Model of Religious Education in Families with Young Children.” International Journal of Children's Spirituality, 12 (1): 37-49. doi:10.1080/ 13644360701266119.

Estep, J. R. \& Breckenridge, L. (2004). The ecology and social dynamic of childhood spirituality. In D. Ratcliff (Ed.), Children's spirituality: Christian perspectives, research, and applications (pp. 249-265). Eugene, OR: Cascade Books.

Fowler, J. 1981. Stages of Faith: The Psychology of Human Development and the Quest for Meaning. San Francisco, CA: Harper \& Row. 30

French, J. R. P., and B. Raven. 1959. The Bases of Social Power. Retrieved from http://www.communicationcache.com/uploads/1/0/8/8/10887248/the_bases_of_social_po wer_-_chapter_20.pdf. 
Hadaway, C. K. (2005). A survey of Christian education and formation leaders serving Episcopal churches. Retrieved from http://archive.episcopalchurch.org/documents/Education-Formation_Report_color.pdf

Haight, W. (2002) African American children at church: A sociocultural perspective. New York, NY: Cambridge University Press.

Haight, W. (2004). A sociocultural perspective on children's spiritual development. In D. Ratcliff (Ed.), Children's spirituality: Christian perspectives, research, and applications (pp. 108-119). Eugene, OR: Cascade Books.

Hart, T. 2006. "Spiritual Experiences and Capacities of Children and Youth.” In The Handbook of Spiritual Development in Childhood and Adolescence, edited by E. C. Roehlkepartain, P. E. King, L. Wangener and P. L. Benson, 163-178. Thousand Oaks, CA: Sage Publications.

Hart, R. A. (1992). Children's participation: From tokenism to citizenship. Innocenti Essays 4, 1-39. Retrieved from http://www.unicefirc.org/publications/pdf/childrens_participation.pdf

Hart, R. A. (2008). Stepping back from 'The Ladder': Reflections on a model of participatory work with children. In R. Alan, B. B. Jensen, J. Nikel, \& V. Simovska, (Eds.), Participation and learning: Perspectives on education and the environment, health and sustainability (19-31). Netherlands: Springer.

Hart, T. (2006). Spiritual experiences and capacities of children and youth. In E. C. Roehlkepartain, P. E. King, L. Wangener, \& P. L. Benson (Eds.), The handbook of spiritual development in childhood and adolescence (pp. 163-177). Thousand Oaks, CA: Sage Publications. 
Hay, D., Nye, R., \& Murphy, R. (1996). Thinking about childhood spirituality: review of research and current directions. In L. J. Francis, W. K. Kay, \& W. S. Campbell (Eds.). Research in religious education (pp. 47-74). Trowbridge, Wiltshire: Redwood Books.

Hay, D. \& Nye, R. (2006). The spirit of the child. (Rev. ed.).[Kindle DX version]. Retrieved from Amazon.com

Hyde, B. (2005). Identifying some characteristics of children's spirituality in Australia primary schools: A study with hermeneutic phenomenology. (Unplublished doctoral thesis). Australian Catholic University, Melbourne. Retrieved from http://dlibrary.acu.edu.au/digitaltheses/public/adt-acuvp82.04092006/02whole.pdf

Hyde, B. (2008). Children and spirituality: Searching for meaning and connectedness. Philadelphia, PA: Jessica Kingsley Publishers.

Hyde, B., Yust, K., \& Ota, C. (2010). Defining childhood at the beginning of the twenty-first century: Children as agents. International Journal of Children's Spirituality, 15, 1-3. http://dx.doi.org/10.1080/13644360903565342

Hood, D. K. (2004). Six children seeking God: Exploring childhood spiritual development in context. In Children's spirituality: Christian perspectives, research, and applications, edited by D. Ratcliff, 249-265. Eugene, OR: Cascade Books.

James, A. \& James, A. L. (2001). Childhood: Toward a theory of continuity and change. The ANNALS of the American Academy of Political and Social Science, 575(25), 25-37. http://dx.doi.org/10.1177/000271620157500102

Lave, J. \& Wenger, E. (1991). Situated learning: Legitimate peripheral participation. New York: NY: Cambridge University Press.

Lings, G. (2013). "What is the DNA of messy church?" In Messy Church Theology: Exploring 
the Significance for the Wider Church, edited by G. Lings, 154-173. Abingdon, OX: The Bible Reading Fellowship.

May, S., Posterski, B., Stonehouse, C., \& Cannell, L. (2005). Children matter: Celebrating their place in the church, family and community. Grand Rapids, MI: William B. Eerdmans Publishing Company.

May, S. \& Ratcliff, D. (2004). Children's spiritual experiences and the brain. In D. Ratcliff(Ed.), Children's spirituality: Christian perspectives, research, and applications (pp. 149-165). Eugene, OR: Cascade Books.

Mercer, J. A. (2005). Welcoming children: A practical theology of childhood. St. Louis, MO: Chalice Press.

Messy Church (2014). Retrieved from http://www.messychurch.org.uk/

Miller-McLemore, B. J. (2003). Let the children come: reimagining childhood from a Christian perspective. San Francisco, CA: Jossey-Bass.

Miller-McLemore, B. J. (2006). Whither the children? Childhood in religious education. The Journal of Religion, 86, 635-657. Retrieved from http://www.jstor.org/stable/10.1086/505897

Miller-McLemore, B. (2010). Children's voices, spirituality, and mature faith. In A. Dillen \& D. Pollefeyt (Eds.), Children's voices: Children's perspectives in ethics, theology and religious education (pp. 17-48). Walpole, MA: Peeters Press.

Ng, D. \& Thomas, V. (1985). Children in the Worshiping Community. Louisville, KY: John Knox Press.

Nye, R. (2004). Christian perspectives on children's spirituality: Social science contributions? In D. Ratcliff (Ed.), Children's spirituality: Christian perspectives, research, and 
applications (pp. 90-107). Eugene, OR: Cascade Books.

Nye, R. (2011). Children's spirituality: What it is and why it matters. [Kindle DX version]. Retrieved from Amazon.com

Off ice of the High Commissioner for Human Rights. (1990). Convention on the rights of the child. Retrieved from http://www.ohchr.org/EN/ProfessionalInterest/Pages/CRC.aspx

Rahner, Karl (1971). Theological investigations (Vol. 8). (D. Bourke, Trans.). New York, NY: Herder and Herder.

Ratcliff, D. (2007). A century of children's spirituality research. Christian Education Journal, $4(2), 218-237$.

Roberto, J. (2009). Becoming intentionally intergenerational: Models and strategies. Lifelong Faith, 3(1), 33-55. Retrieved from http://www.lifelongfaith.com/uploads/5/1/6/4/5164069/lifelong_faith_journal_3.1.pdf

Roehlkepartain, E. C. (2004). Exploring scientific and theological perspectives on children's spirituality. In D. Ratcliff (Ed.), Children's spirituality: Christian perspectives, research, and applications (pp. 120-132). Eugene, OR: Cascade Books.

Roehlkepartain, E. C. \& Patel, E. (2006). Congregations: Unexamined crucibles for spiritual development. In E. C. Roehlkepartain, P. E. King, L. Wangener, \& P. L. Benson (Eds.), The handbook of spiritual development in childhood and adolescence (pp. 324-336). Thousand Oaks, CA: Sage Publications.

Ruppell, J.(2004). Using developmentally appropriate practice in faith-based early childhood settings. In D. Ratcliff (Ed.), Children's spirituality: Christian perspectives, research, and applications (pp. 343-357). Eugene, OR: Cascade Books. 
Thomson, D. R. (2009). Growing in favor with God: Young children's spiritual development and implications for Christian education. (unpublished Doctoral dissertation). University of North Texas, Denton, TX. UNT Digital Library. Retrieved from http://digital.library.unt.edu/ark:/67531/metadc9823/

Tolbert, L. V. \& Brownlee, M. (2008). The African American church and its role in nurturing the spiritual development of children. In H. C. Allen (Ed.), Nurturing children's spirituality: Christian perspectives and best practices (pp. 320-340). Eugene, OR: Cascade Books.

Ward, T. (1995). Foreword. In J. C. Wilhoit, \& J. M. Dettoni, (Eds.), Nurture that is Christian: Developmental perspectives on Christian education (pp. 7-17). Grand Rapids, MI: Baker Books.

Westerhoff, J. H. (1976). Will our children have faith?. Harrisburg, PA: Seabury Press.

White, K. J. \& Willmer, H. (2006). An introduction to child theology. In M. J. Bunge (Ed). Key Topics in Child Theology. London, UK: The Child Theology Movement Limited. Retrieved from http://www.childtheology.org/wp-content/uploads/2013/02/Booklet1text-Revised-June-2008.txt

Yust, K. M. (2002). Theology, educational theory, and children's faith formation: Findings from the faith formation in children's ministries project. Faith Formation Learning Exchange. Retrieved from http://www.faithformationlearningexchange.net/uploads/5/2/4/6/5246709/children_faith_ formation_research_project_-_yust.pdf 